\title{
Solubility and Dissolved Cellulose in Aqueous Calcium- and Sodium-Thiocyanate Solution
}

\author{
Makiko Hattori, Yoshihiko Shimaya, and Masatoshi Saito \\ Central Laboratory, Asahi Chemical Industry Co., Ltd., \\ 11-7 Hacchonawate, Takatsuki, Osaka 569, Japan
}

(Received June 16, 1997)

\begin{abstract}
Attempt was made to investigate the solubility and the dissolved state of various celluloses in aqueous (aq) calcium- and sodium-thiocyanate solution. Almost all celluloses used in this study were soluble in $55 \mathrm{wt} \%$ aq calcium thiocyanate $\left(\mathrm{Ca}(\mathrm{SCN})_{2}\right)$ soln. at about $100^{\circ} \mathrm{C}$, while $60 \mathrm{wt} \%$ aq sodium thiocyanate $(\mathrm{NaSCN})$ soln. dissolves only limited cellulose mainly regenerated from cellulose solution. The solubility of cellulose in $60 \mathrm{wt} \%$ aq NaSCN was independent of the crystal form, crystallinity and the degree of polymerization of cellulose and this was explained only in terms of the degree of breakdown of intramolecular hydrogen bonds in the cellulose solid. Using 2-dimensional NMR six carbon peaks in ${ }^{13} \mathrm{C}$ NMR spectra of cellulose in two solvents were successfully assigned. The comparison of chemical shifts of cellulose in $55 \mathrm{wt} \%$ aq $\mathrm{Ca}(\mathrm{SCN})_{2}$ solution and $10 \%$ sodium hydroxide $(\mathrm{NaOH})$ solution strongly suggested that calcium atoms as electron acceptors coordinate with oxygen atoms in glucose ring and primary alcohol at $\mathrm{C}(6)$ position, in the same manner of cellulose dipped in $55 \mathrm{wt} \%$ aq $\mathrm{Ca}(\mathrm{SCN})_{2}$ solution at room temperature. In the ${ }^{13} \mathrm{C}$ NMR spectrum of cellulose- $60 \%$ aq $\mathrm{NaSCN}$ solution system, $\mathrm{C}(3)$, $\mathrm{C}(2)$, and $\mathrm{C}(6)$ peaks were observed at lower magnetic field side, implying that sodium atoms interact with hydroxide groups at $\mathrm{C}(2), \mathrm{C}(3)$, and $\mathrm{C}(6)$ positions of glucopyranose in cellulose molecules.

KEY WORDS Cellulose / Calcium Thiocyanate Solution / Sodium Thiocyanate Solution / Solubility / Hydrogen Bond / Nuclear Magnetic Resonance / Dissolved State /
\end{abstract}

Recently, cellulose has been attracting attention, because of its natural reproductivity and high biodegradability. But solvents were very limited in metal complexes, strong acids and salts, due to highly developed intra- and intermolecular hydrogen bonds in cellulose solid. ${ }^{1}$ For these thirty years, new organic and inorganic solvents, such as $N, N$-dimethylacetamide (DMAc)/lithium chloride $(\mathrm{LiCl})^{2,3}$ and amine oxide containing water, ${ }^{4}$ liquid ammonia/ammonia thiocyanate, ${ }^{5,6}$ and aqueous (aq) sodium hydroxide $(\mathrm{NaOH})^{7-9}$ have been found and the dissolving mechanisms of cellulose into these solvents have been intensively investigated. For some solvents, the solubility of cellulose is exclusively governed by the structure of cellulose solid. For example, natural cellulose can be dissolved in $7-9 \mathrm{wt} \%$ aq $\mathrm{NaOH}$ solution near $4^{\circ} \mathrm{C}$, only when intramolecular hydrogen bonds, estimated by solid state NMR, are destroyed to some extent. $^{8,9}$ Recently, Saito and Shimaya ${ }^{10,11}$ found that concentrated aq sodium thiocyanate $(\mathrm{NaSCN})$ solution at about $100^{\circ} \mathrm{C}$ is able to dissolve the cellulose regenerated from cellulose solution but not natural cellulose, while aq calcium thiocyanate $\left(\mathrm{Ca}(\mathrm{SCN})_{2}\right)$ dissolves both at the same temperature. Relationship between solubility in aq NaSCN soln. and solid structure of cellulose is not known yet. As far as conc. aq $\mathrm{Ca}(\mathrm{SCN})_{2}$ is concerned, our previous work on its swelling behavior towards natural cellulose at lower temperature region where cellulose could not be dissolved, has revealed that the undissociated $\mathrm{Ca}(\mathrm{SCN})_{2}$-water complexes penetrate the amorphous and the interplanar spacings of $(1 \overline{1} 0)$ and (110) crystal plane, forming complexes with ring oxygen and primary alcohol oxygen at $\mathrm{C}(6)$ position in glucopyranose ring of cellulose. ${ }^{12,13}$ However, the dissolved state of cellulose in the calcium thiocyanate has not been disclosed.

In this paper attempt is made to obtain more detailed information of the effects of cellulose solid structure on solubility into aq sodium thiocyanate solution and study the dissolved state of cellulose in aq sodium- and calcium thiocyanate solutions based on the data of two-dimensional NMR.

\section{EXPERIMENTAL}

\section{Samples}

Several natural and regenerated cellulose samples summarized in the first and second columns of Table I were used for dissolution tests. Conifer pulp (Sample code, CP) is manufactured by Alaska Pulp Co. (U.S.A.) using sulfite pulping method. HP is a hydrolyzed conifer pulp in $25 \mathrm{wt} \%$ aq $\mathrm{H}_{2} \mathrm{SO}_{4}$ for $2 \mathrm{~h}$ at $50^{\circ} \mathrm{C}$. Commercially available sanitary cotton (Cotton) was supplied from Nankai Sangyou Co. (Osaka). Bactrial cellulose (BC) prepared in our laboratory using Acetovactor xylinum and purified ${ }^{14}$ was used after washing in water followed by drying. Tunica of Halocynthia roretzi was treated by aq $5 \mathrm{wt} \% \mathrm{KOH}$ and $0.3 \mathrm{wt} \% \mathrm{NaClO}_{2}$ solutions, ${ }^{15}$ obtaining purified tunicated cellulose (TC). Among cellulose samples with crystal form II, a sample NOpulp was prepared by dipping conifer pulp into $17.5 \mathrm{wt} \%$ aq $\mathrm{NaOH}$ soln. for 6 days at room temperature, and CApulp was prepared from HP by dipping into a mixture of cuprammonium solution and $3 \mathrm{wt} \%$ aq $\mathrm{NaOH}$ solution $(1: 4, \mathrm{w} / \mathrm{w})$ at $15^{\circ} \mathrm{C}$ for 1 day, washed with methanolwater $(1: 1, \mathrm{v} / \mathrm{v})$ mixture, followed by regeneration and removement of remaining copper by dilute hydrochloric acid/methanol solution.

To investigate the effects of the hydrogen bondings in cellulose solid on the solubility against aq sodium thiocyanate solutions, methyl cellulose (MC) with different degrees of substitution $\langle\mathrm{F}\rangle$ was prepared: Bemlise ${ }^{\circledR}$ (Asahi Chemical Industry, sample code CAR-2) hydrolyzed using $25 \mathrm{wt} \%$ aq sulfuric acid was dissolved into $9 \mathrm{wt} \%$ aq $\mathrm{NaOH}$ soln. to give a $6.5 \mathrm{wt} \%$ cellulose so- 
Table I. Charasteristics of various celluloses and the solubility toward aq $\mathrm{Ca}(\mathrm{SCN})_{2}$ and $\mathrm{NaSCN}$ soln.

\begin{tabular}{|c|c|c|c|c|c|c|c|c|c|c|c|}
\hline \multirow{2}{*}{$\begin{array}{l}\text { Sample } \\
\text { code }\end{array}$} & \multirow{2}{*}{ Resources } & \multirow{2}{*}{$\begin{array}{l}\text { Crystal } \\
\text { type }\end{array}$} & \multirow{2}{*}{$\frac{\text { Crystalinity }}{\%}$} & \multicolumn{4}{|c|}{ Crystalline size/nm } & \multirow{2}{*}{$D P_{\mathrm{v}}$} & \multirow{2}{*}{$\frac{\chi_{\mathrm{am}}\left(\mathrm{C}_{3}\right)}{\%}$} & \multicolumn{2}{|c|}{ Solubility } \\
\hline & & & & $(1 \overline{1} 0)$ & $(110)$ & $(200)$ & Mean & & & $\mathrm{Ca}(\mathrm{SCN})_{2}$ & $\mathrm{NaSCN}$ \\
\hline $\mathrm{CP}$ & Conifer pulp & $\mathrm{I}_{\beta}$ rich & 53.8 & 4.2 & 4.1 & 4.0 & 4.1 & 970 & 50 & 0 & $x$ \\
\hline HP & Hydrolyzed pulp & $\mathrm{I}_{\beta}$ rich & - & - & - & - & - & 425 & 43 & 0 & $x$ \\
\hline Cotton & Sanitary cotton & $\mathrm{I}_{\beta}^{p}$ rich & 70.5 & - & - & - & & - & 39 & $\mathrm{O}$ & $x$ \\
\hline $\mathrm{BC}$ & Bacterial cellulose & $\mathrm{I}_{\alpha}^{p}$ rich & 85.0 & - & - & - & - & - & 33 & 0 & $x$ \\
\hline $\mathrm{TC}$ & Tunicate cellulose & $\mathrm{I}_{\beta}$ & ca. 90.0 & - & - & - & - & - & - & $\bigcirc$ & $x$ \\
\hline Rayon & Viscose rayon & II & 22.1 & - & - & - & - & 340 & 61 & 0 & 0 \\
\hline $\mathrm{CAF}$ & Regenerated from $55 \mathrm{wt} \%$ aq $\mathrm{Ca}(\mathrm{SCN})_{2}$ & II & 41.8 & 3.2 & 3.1 & 3.6 & 3.3 & 500 & 66 & O & 0 \\
\hline NOF & Regenerated from $9 \%$ aq $\mathrm{NaOH}$ & II & 43.1 & 3.0 & 4.5 & 4.8 & 4.1 & 330 & - & O & O \\
\hline OSR & Organic spun rayon & II & 45.9 & - & - & - & - & 600 & 58 & $\mathrm{O}$ & $\bigcirc$ \\
\hline CAR-1 & Cuprammonium rayon fiber & II & 38.2 & 5.0 & 4.3 & 4.1 & 4.5 & 820 & 63 & $\bigcirc$ & $\bigcirc$ \\
\hline CAR-2 & Cuprammonium rayon non-woven fabric & II & 18.1 & - & - & - & - & 870 & 64 & $\mathrm{O}$ & $\mathrm{O}$ \\
\hline NOpulp & $\begin{array}{l}\mathrm{CP} \text { treated by } 17.5 \mathrm{wt} \% \text { aq } \mathrm{NaOH} \& \\
\text { recovered by water }\end{array}$ & II & 30.9 & 5.0 & 4.8 & 5.0 & 4.9 & - & 47 & 0 & $x$ \\
\hline CApulp & $\begin{array}{l}\text { HP treated by cuprammonium \& } \\
\text { recovered by acetone }\end{array}$ & $\begin{array}{c}\text { I } \\
\& I I\end{array}$ & $\begin{array}{l}14.9 \\
18.9\end{array}$ & $\begin{array}{l}4.4 \\
2.7\end{array}$ & $\begin{array}{l}3.1 \\
3.0\end{array}$ & $\begin{array}{l}3.8 \\
4.1\end{array}$ & $\begin{array}{l}3.8 \\
3.3\end{array}$ & 425 & 61 & $\bigcirc$ & O \\
\hline
\end{tabular}

lution. $^{7} 3.0 \mathrm{~mol}$ of dimethyl sulfate against a glucose unit of cellulose were added to the cellulose solution at $0^{\circ} \mathrm{C}$ with agitation. The methylation proceeded for desired time from 5 to $60 \mathrm{~min}$. The MC thus synthesized was recovered from reaction media using $10 \mathrm{wt} \%$ aq acetic acid soln. and washed in water and water/methanol mixture. $\langle\mathrm{F}\rangle\rangle$ of the recovered $\mathrm{MC}$ was determined by NMR method using dimethyl sulfoxide- $d_{6}$ as solvent and was found to be 0.77 (sample code MC1), 1.04 (MC2), 1.65 (MC3), 1.88 (MC4) corresponding to the reaction time 5, 15, 30, $60 \mathrm{~min}$.

\section{Characterization of the Cellulose Samples}

Wide angle X-ray diffraction measurements on the cellulose samples in Table I were carried out under the following conditions: Incident beam, $\mathrm{Cu}-K_{\alpha}$ ray; accelerating voltage, $45 \mathrm{kV}$; beam current, $300 \mathrm{~mA}$. The diffractogram was recorded on a X-ray diffraction instrument RU-300 (Rigaku, Tokyo). Crystallinity $\chi_{\mathrm{c}}$ was estimated by peak separation. Apparent crystalline size (ACS) was calculated from half value width of (110), (110), and (200) crystal planes through Scherrer's equation as follows ${ }^{16}$ :

$$
\begin{gathered}
\mathrm{ACS}=0.9 \lambda /(\cos \theta \cdot \beta) \\
\beta=\left(B^{2}-b^{2}\right)^{1 / 2} \quad \text { (in Radian) }
\end{gathered}
$$

Where $\lambda$ is the wave length of the incident beam $(0.1542 \mathrm{~nm}) ; \theta$, Bragg's angle; $B$, half width of the peak for each plane; $b$, instrumental constant ( 0.2 degree).

The viscosity-average molecular weight $M_{\mathrm{v}}$ was evaluated from the limiting viscosity number $[\eta]$ of the cellulose sample in cadoxen at $25^{\circ} \mathrm{C}$ through viscosity equation as follows ${ }^{17}$ :

$$
[\eta]=3.85 \cdot 10^{-2} \cdot M_{w}^{0.76}\left(\mathrm{~cm}^{3} \mathrm{~g}^{-1}\right)
$$

Here, $M_{w}$ is the weight-average molecular weight. The viscosity-average degree of polymerization $D P_{\mathrm{v}}$ was converted from $M_{\mathrm{v}}$ obtained.

The degree of breakdown of intramolecular hydrogen bonds $\left(\chi_{\mathrm{am}}(\mathrm{C} 3)\right)$ was evaluated from the peak area ratio of $\mathrm{C}(4)$ peak in CP/MAS ${ }^{13} \mathrm{C}$ NMR spectrum of the each sample, according to the method described in the literature. ${ }^{9}$ The conditions of NMR were as follows: Instrument, GSX400 (JEOL); flip angle, 90 degree; width, $5 \mu \mathrm{s}$; cross-polarization contact time, $1-2 \mu \mathrm{s}$; data points, 8192; number of scanning, 512 or 2048 times; external standard, adamantane (upfield peak, $\delta=29.5$ ppm).

\section{Solubility of Cellulose}

A mixture of the cellulose sample and $55 \mathrm{wt} \%$ aq calcium- or $60 \mathrm{wt} \%$ aq sodium thiocyanate soln. (cellulose $/$ solvent $=0.01 / 0.99, \mathrm{w} / \mathrm{w}$ ) was stocked for 1 day at room temperature, followed by heating for $3 \mathrm{~h}$ at $120^{\circ} \mathrm{C}$ with stirring. When the transparent solution was obtained, the sample was judged as dissolved.

\section{Differential Scanning Calorimetry}

About 5mg of cellulose or MC samples were loaded in stainless seal cell. DSC measurements were carried out just after ca. $20 \mathrm{mg}$ of $60 \mathrm{wt} \%$ aq NaSCN soln. was added to the cellulose or MC samples in the cell. DSC thermograms were recorded on DSC type 200 (Seiko Electronic, Tokyo) with heating rate of $3^{\circ} \mathrm{C} \mathrm{min}^{-1}$ up to $155^{\circ} \mathrm{C}$.

\section{$\mathrm{NMR}$ of Cellulose $/ \mathrm{Ca}(\mathrm{SCN})_{2}-$ and $\mathrm{NaSCN}-\mathrm{D}_{2} \mathrm{O}$ Solu- tion Systems}

The hydrolyzed Bemlise ${ }^{\circledR}$ with $D P_{\mathrm{v}}=30$ was dissolved in $60 \mathrm{wt} \% \mathrm{NaSCN} / \mathrm{D}_{2} \mathrm{O}$ and $55 \mathrm{wt} \% \mathrm{Ca}(\mathrm{SCN})_{2} / \mathrm{D}_{2} \mathrm{O}$ solutions at $c a .100^{\circ} \mathrm{C}$, giving $1-7 \mathrm{wt} \%$ cellulose solutions. The $1 \mathrm{wt} \%$ solutions were used for onedimensional (1D) ${ }^{1} \mathrm{H}$ NMR measurement, $3 \mathrm{wt} \%$ solutions for $1 \mathrm{D}{ }^{13} \mathrm{C}$ NMR and ${ }^{1} \mathrm{H}-{ }^{1} \mathrm{H}$ two dimensional shift correlated NMR $\left({ }^{1} \mathrm{H}-{ }^{1} \mathrm{H}\right.$ COSY $)$ ones and 6 and $7 \mathrm{wt} \%$ solutions for ${ }^{13} \mathrm{C}-{ }^{1} \mathrm{H}$ two dimensional shift correlated NMR $\left({ }^{13} \mathrm{C}-{ }^{1} \mathrm{H}\right.$ COSY $)$ ones.

NMR measurements were made on a GSX-400 FTNMR spectrometer (JEOL, Tokyo) at $399.78 \mathrm{MHz}$ for ${ }^{1} \mathrm{H}$ and $100.54 \mathrm{MHz}$ for ${ }^{13} \mathrm{C}$. ${ }^{1} \mathrm{H}$ and ${ }^{13} \mathrm{C}$ chemical shifts for cellulose were determined from 1D NMR spectra, independently measured, by an internal reference of sodium 3-trimethylsilylpropionate-2,2,3,3- $d_{4}$ (TSP, $0 \mathrm{ppm}$ ), under the following conditions: Spectrum width, $8 \mathrm{kHz}$ for ${ }^{1} \mathrm{H} \mathrm{NMR}, 25 \mathrm{kHz}$ for ${ }^{13} \mathrm{C}$ NMR; pulse 
Table II. Experimental conditions in COSY measurements

\begin{tabular}{|c|c|c|c|c|c|c|c|}
\hline \multirow{2}{*}{ Solvent } & Cell. conc. & Temp & Pulse Delay & $90^{\circ}$ pulse width & Spectral width & \multirow{2}{*}{ Data matrix $^{a}$} & Accumulation \\
\hline & $w t \%$ & ${ }^{\circ} \mathrm{C}$ & s & $\mu \mathrm{s}$ & $\mathrm{Hz}$ & & times \\
\hline $\begin{array}{l}60 \mathrm{wt} \% \\
\mathrm{NaSCN} / \mathrm{D}_{2} \mathrm{O}\end{array}$ & 3 & 100 & 1.5 & 25.0 & 800 & $\begin{array}{c}2048 \times 256 \\
(2048 \times 512)\end{array}$ & 8 \\
\hline
\end{tabular}

${ }^{a}$ Numbers in parentheses indicate expanded matrixes by zero-filling.

Table III. Experimental conditions for C-H COSY measurements

\begin{tabular}{|c|c|c|c|c|c|c|c|c|c|c|}
\hline \multirow{2}{*}{ Solvent } & Cell. conc. & Temp & Pulse delay & $\begin{array}{c}{ }^{1} \mathrm{H} 90^{\circ} \text { Pulse } \\
\text { width }\end{array}$ & $\begin{array}{c}{ }^{13} \mathrm{C} 90^{\circ} \text { Pulse } \\
\text { width }\end{array}$ & $\begin{array}{c}{ }^{1} \mathrm{H} \text { Spectral } \\
\text { width }\end{array}$ & $\begin{array}{c}{ }^{13} \mathrm{C} \text { Spectral } \\
\text { width }\end{array}$ & PI3 & \multirow{2}{*}{ Data matrix ${ }^{a}$} & Accumulation \\
\hline & $w t \%$ & ${ }^{\circ} \mathrm{C}$ & $\mathrm{s}$ & $\mu \mathrm{s}$ & $\mu \mathrm{s}$ & $\mathrm{Hz}$ & $\mathrm{Hz}$ & $\mathrm{ms}$ & & times \\
\hline \multirow{2}{*}{$\begin{array}{l}55 \mathrm{wt} \% \\
\mathrm{Ca}(\mathrm{SCN})_{2} / \mathrm{D}_{2} \mathrm{O} \\
60 \mathrm{wt} \% \\
\mathrm{NaSCN} / \mathrm{D}_{2} \mathrm{O}\end{array}$} & 7 & 100 & 2.0 & 18.9 & 16.0 & 800 & 8000 & 1.786 & \multirow{2}{*}{$\begin{array}{c}2048 \times 256 \\
(2048 \times 512) \\
2048 \times 256 \\
(2048 \times 512)\end{array}$} & 416 \\
\hline & 6 & 100 & 1.5 & 24.0 & 15.0 & 800 & 6002.4 & 1.786 & & 280 \\
\hline
\end{tabular}

a Numbers in parentheses indicate expanded matrixes by zero-filling.

interval, 3, 2.5s; pulse width for ${ }^{1} \mathrm{H}$ NMR, $10 \mu \mathrm{s}$ (45degree pulse) for $\mathrm{Ca}(\mathrm{SCN})_{2}$ system, $12.5 \mu \mathrm{s}$ (45 degree pulse) for NaSCN system; pulse width for ${ }^{13} \mathrm{C}$ NMR, $6 \mu \mathrm{s}$; number of accumulation, 8 and 20,000 times for ${ }^{1} \mathrm{H}$ and ${ }^{13} \mathrm{C} \mathrm{NMR}$, respectively.

${ }^{1} \mathrm{H}-{ }^{1} \mathrm{H}$ COSY and ${ }^{13} \mathrm{C}-{ }^{1} \mathrm{H}$ COSY measurements were performed on the same instrument mentioned-above at $100^{\circ} \mathrm{C}$. The conditions for both measurements are summarized in Tables II and III. The mixing time PI3 for ${ }^{13} \mathrm{C}-{ }^{1} \mathrm{H}$ COSY measurements was set up to be $1.786 \mathrm{~ms}\left(=1 /\left(4 J_{\mathrm{C}-\mathrm{H}}\right)\right)$, where $J_{\mathrm{C}-\mathrm{H}}$ is the coupling constant between $\mathrm{C}$ and $\mathrm{H}$ nuclei.

\section{RESULTS AND DISCUSSION}

\section{Solubility of Various Celluloses in aq Calcium and Sodium Thiocyanate}

The characteristics and solubility of various celluloses are listed in Table I. The crystal type of natural celluloses was quoted from the literature. ${ }^{18}$ The hydrolyzed pulp treated by cuprammonium/ $\mathrm{NaOH}$ mixture (sample code CApulp) included cellulose-I and II crystals. The solubility of cellulose against two aq thiocyanate solutions is quite different. $55 \mathrm{wt} \%$ aq $\mathrm{Ca}(\mathrm{SCN})_{2}$ soln. dissolves all kinds of celluloses almost perfectly, irrespective of crystal types, i.e., $\mathrm{I}_{\alpha}, \mathrm{I}_{\beta}$, II, crystallinity, ACS and the degree of polymerization of the original cellulose samples. Note here that $D P_{\mathrm{v}}$ of recovered sample CP from the solution, prepared at $120^{\circ} \mathrm{C}$ for $4 \mathrm{~h}$, was 779 . This value is only $20 \%$ less than that of the sample CP before dissolution, indicating that dissolution of cellulose into $55 \mathrm{wt} \%$ aq $\mathrm{Ca}(\mathrm{SCN})_{2}$ soln. does not occur by hydrolysis.

$60 \mathrm{wt} \% \mathrm{NaSCN}$ soln. does not dissolve and even swell the treated and untreated natural cellulose. But it gives almost completely transparent solution for the cellulose regenerated from the solution and the cellulose with both crystal forms I and II (CApulp). Their solubility is at least independent of $\chi_{\mathrm{c}}$ and $D P_{\mathrm{v}} .60 \mathrm{wt} \%$ aq NaSCN cannot dissolve the cellulose with crystal form II,

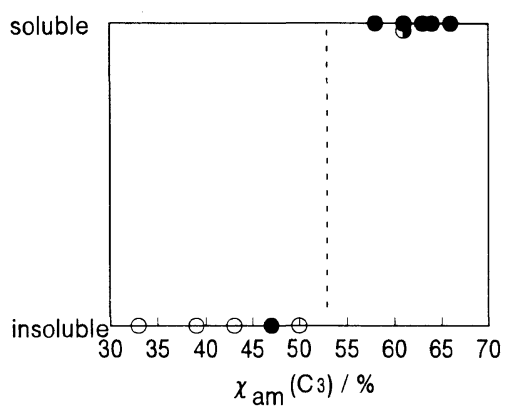

Figure 1. Relationship between the solubility of the samples in Table I against $60 \mathrm{wt} \%$ aq NaSCN soln. and $\chi_{\mathrm{am}}(\mathrm{C} 3)$. $\mathrm{O}$, cellulose I; $\bullet$, cellulose II; $\mathbf{D}$, mixture of celluloses I and II.

obtained by alkali treatment (NOpulp). These facts suggest that crystal form is not a decisive factor controlling solubility toward aq $\mathrm{NaSCN}$. It should be noted that increase in the solubility of the CApulp, comparing to hydrolyzed pulp (sample HP), is not related to the degree of polymerization, because $D P_{\mathrm{v}}$ is almost invariable after treatment of cuprammonium $/ \mathrm{NaOH}$ mixture.

Figure 1 shows the relationship between the solubility in aq $\mathrm{NaSCN}$ and degree of breakdown of intramolecular hydrogen bonds of $\mathrm{C}(3)-\mathrm{OH} \cdots \mathrm{O}\left(5^{\prime}\right)\left[\chi_{\mathrm{am}}(\mathrm{C} 3)\right]$ for the samples. In the figure filled and unfilled circles denote the cellulose with crystal forms II and I, respectively, and a half-filled circle denotes the cellulose with celluloses I and II crystals. The effect of intramolecular hydrogen bondings on the solubility is remarkable, as has been proved for cellulose solubility in $9 \%$ aq $\mathrm{NaOH}$ soln. ${ }^{9}$ Soluble-insoluble border seems to be about $55 \%$ of $\chi_{\mathrm{am}}(\mathrm{C} 3)$ (broken line). This value is almost the same in the case of $\mathrm{NaOH}$ system. ${ }^{9} \chi_{\mathrm{am}}(\mathrm{C} 3)$ might also reflect the degree of breakdown of intermolecular hydrogen bonds since there has been pointed out that some intermolecular hydrogen bonds exist connecting the $\mathrm{C}(3) \mathrm{OH} \cdots \mathrm{O}\left(5^{\prime}\right)$ intramolecular hydrogen bonds. The above solubility results suggest that the interaction of $\mathrm{NaSCN}$ with cellulose solid is quite different from that of $\mathrm{Ca}(\mathrm{SCN})_{2}$. 


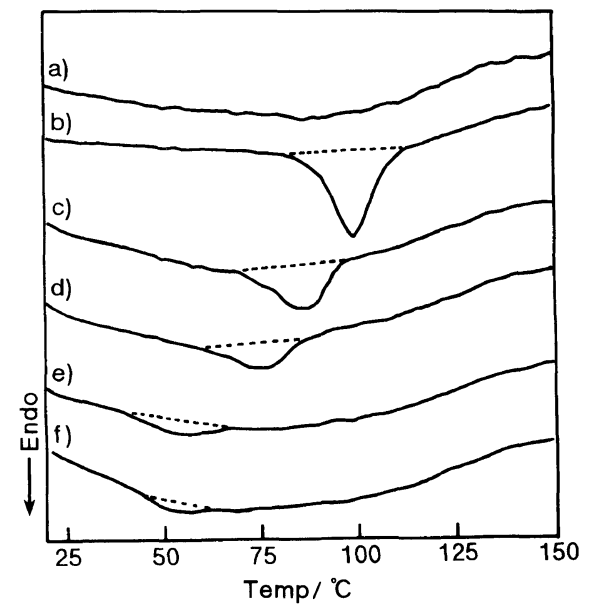

Figure 2. DSC curves of the samples CP (a), CAR-2 (b), and $\mathrm{MCl}-4$ (c-f) in $60 \mathrm{wt} \%$ aq sodium thiocyanate soln. on heating.

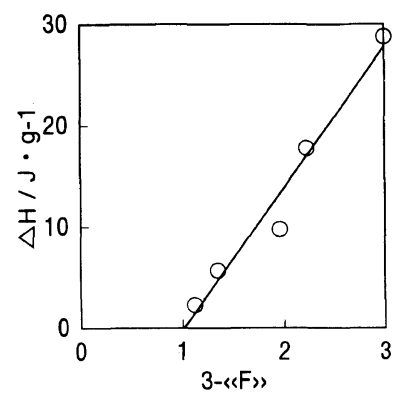

Figure 3. The relationship between endothermic heat $\Delta H$ of methyl cellulose and $(3-\langle\mathrm{F}\rangle)$.

\section{Interaction of Sodium Thiocyanate with Cellulose}

Figure 2 shows DSC curves of the samples CP (a), CAR-2 (b), and MC1-4 (c-f) in $60 \mathrm{wt} \%$ aq $\mathrm{NaSCN}$ soln. on heating. The insoluble CP sample shows no peak during heating, but the soluble sample CAR-2, cellulose regenerated from cuprammonium soln., reveals an endothermic peak near dissolution temperature. In the previous paper $^{12}$ we reported that cellulose- $55 \mathrm{wt} \%$ aq $\mathrm{Ca}(\mathrm{SCN})_{2}$ soln. exhibits an exothermic DSC peak attributable to cellulose-aq $\mathrm{Ca}(\mathrm{SCN})_{2}$ complex formation far below the dissolution temperature and shows no peak near the actual dissolving temperature. This quite different behavior of $\mathrm{Ca}(\mathrm{SCN})_{2}$ suggests that aq $\mathrm{NaSCN}$ molecules do not form complexes with cellulose molecules and the endothermic peak in the DSC thermogram of the regenerated cellulose arises from destruction of hydrogen bonds and fusion of crystalline part.

Samples MC1 and 2 with $\langle\bar{F}\rangle=0.77$ and 1.04 clearly dissolve in $60 \mathrm{wt} \%$ aq $\mathrm{NaSCN}$ soln. But the solubility of MC monotonically decreases with increase of $\langle\mathrm{F}\rangle$. In Figure 3, endothermic heat $\Delta H$ of methyl cellulose is plotted against residual $\mathrm{OH}$ probability $(3-\langle\mathrm{F}\rangle)$. The decrease in $\langle\langle\mathrm{F}\rangle$ brings about increase in $\Delta H$, just corresponding to the solubility. This indicates that endothermic heat $\Delta H$ evolves from interactions of hydroxyl groups in cellulose with aq NaSCN. The limited methylation of cellulose may break the intra- and intermolecular hydrogen bonds at least partly, leading to an increase in the solubility. This seems evidence that NaSCN molecules interact with hydroxyl group and dissolve cellulose only when hydrogen bondings are

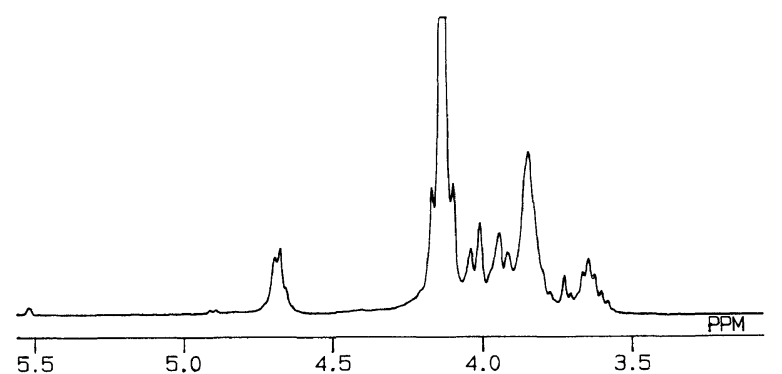

Figure 4. $1 \mathrm{D}{ }^{1} \mathrm{H}$ NMR spectrum of hydrolyzed regenerated cellulose with $D P_{\mathrm{v}}=30$ in $\mathrm{Ca}(\mathrm{SCN})_{2}-\mathrm{D}_{2} \mathrm{O}$ system at $100^{\circ} \mathrm{C}$.

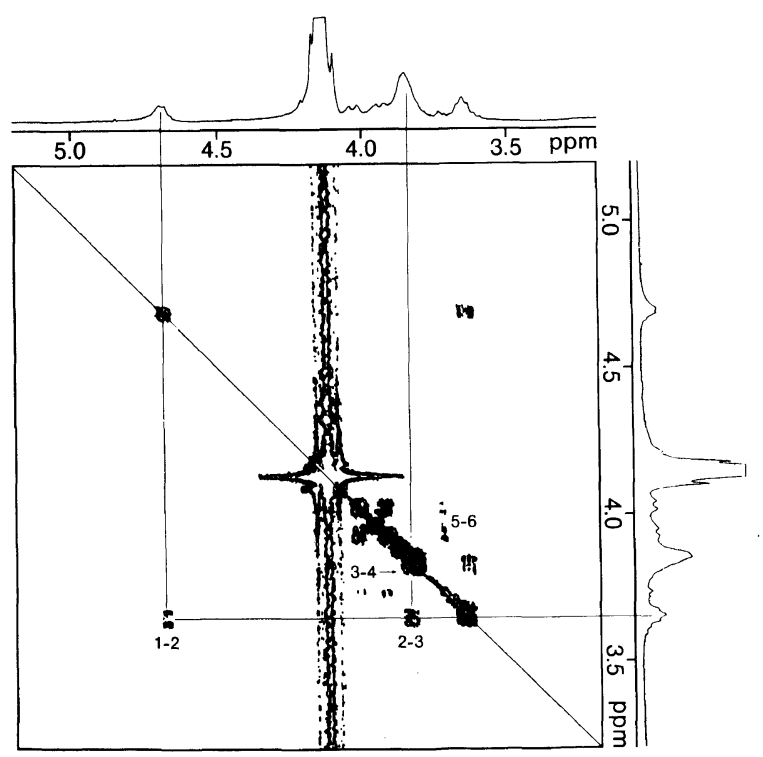

Figure 5. $\quad{ }^{1} \mathrm{H}-{ }^{1} \mathrm{H}$ COSY spectrum of hydrolyzed regenerated cellulose with $D P_{\mathrm{v}}=30$ in $\mathrm{Ca}(\mathrm{SCN})_{2}-\mathrm{D}_{2} \mathrm{O}$ system at $100^{\circ} \mathrm{C}$.

partially broken down in the cellulose solid.

NMR Spectra of Cellulose/aq $\mathrm{Ca}(\mathrm{SCN})_{2}$ Solution System

1D ${ }^{1} \mathrm{H}$ NMR spectrum of hydrolyzed regenerated cellulose with $D P_{\mathrm{v}}=30$ in $\mathrm{Ca}(\mathrm{SCN})_{2}-\mathrm{D}_{2} \mathrm{O}$ system is shown in Figure 4. ${ }^{1} \mathrm{H}-{ }^{1} \mathrm{H}$ COSY spectrum of the same system is depicted in Figure 5. Despite homogate decoupling, a very large peak due to residual proton in the solvent was observed at $\delta_{\mathrm{H}}=4.13 \mathrm{ppm}$. The peaks observed near 4.9 and $5.5 \mathrm{ppm}$ in Figure 4 are attributable to hydroxyl groups in the pyranose ring. However, these peaks are too weak in intensity probably due to deuteration by solvent and rapid exchanging with residual $\mathrm{H}_{2} \mathrm{O}$, and could not be used effectively in analyzing the ${ }^{1} \mathrm{H}-{ }^{1} \mathrm{H}$ COSY spectrum. A broad peak centered at chemical shift $\delta_{\mathrm{H}}=3.84 \mathrm{ppm}$ is relatively higher in intensity than those of the other peaks, suggesting that the broad peak includes some proton peaks. The peak near $\delta_{\mathrm{H}}=4.7 \mathrm{ppm}$ is a doublet $\left(\delta_{\mathrm{H}}=4.675\right.$ and $4.695 \mathrm{ppm}$ ) and appears at the lowest magnetic field, except for the peaks of the hydroxyl protons, supporting that this peak is attributed to anomeric protons at $\mathrm{C}(1)$ carbon position $(\mathrm{H}(1)) .{ }^{19} 2$ doublet peaks are seen in $\delta_{\mathrm{H}}=3.9-4.1 \mathrm{ppm}$ and two complex peak groups are seen at $\delta_{\mathrm{H}}=3.7$, and $3.6 \mathrm{ppm}$. In Figure 5, diagonal peaks correspond to each peak in the 1D spectrum and cross-peaks exhibit coupling between neighboring protons. Accordingly, a complex (triplet) proton peak 


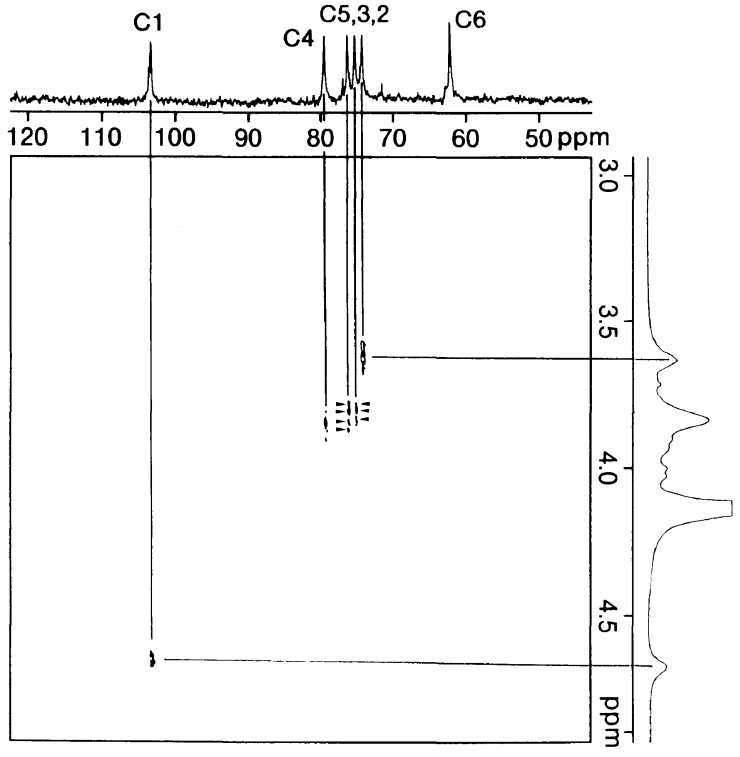

Figure 6. ${ }^{13} \mathrm{C}-{ }^{1} \mathrm{H} \quad \mathrm{COSY}$ spectrum of hydrolyzed regenerated cellulose with $D P_{\mathrm{v}}=30$ in $\mathrm{Ca}(\mathrm{SCN})_{2}-\mathrm{D}_{2} \mathrm{O}$ at $100^{\circ} \mathrm{C}$. Horizontal and longitudinal axes are ${ }^{13} \mathrm{C}$ and ${ }^{1} \mathrm{H}$ chemical shifts and projections on the axes are ${ }^{13} \mathrm{C}$ and ${ }^{1} \mathrm{H}$ NMR spectra, respectively.

near $\delta_{\mathrm{H}}=3.6 \mathrm{ppm}$ in 1D spectrum reveals vicinal coupling with the $\mathrm{H}(1)$ peak at $\delta_{\mathrm{H}}=4.675-4.695 \mathrm{ppm}$ and is assigned to $H(2)$. The triplet nature of the $H(2)$ peak probably means that the coupling constants $J_{\mathrm{H}(1)-\mathrm{H}(2)}$ and $J_{\mathrm{H}(2)-\mathrm{H}(3)}$ are almost equal. The triplet $\mathrm{H}(2)$ peaks are also closely correlated with a broad peak at 3.805 , 3.825 , and $3.845 \mathrm{ppm}$ (these positions are higher magnetic field region of the broad peak centered at $3.84 \mathrm{ppm}$ ), indicating that the overlapped broad peak contains $\mathrm{H}(3)$ protons in the higher magnetic range of $3.80-3.84 \mathrm{ppm}$. The cross peaks of $\mathrm{H}(3)-\mathrm{H}(4)$ and $\mathrm{H}(4)-\mathrm{H}(5)$ closely overlapped with each autocorrelation peak. But close inspection reveals that one of $\mathrm{H}(3)$ peaks at $\delta_{\mathrm{H}}=3.805$ ppm has cross-peak at $\delta_{\mathrm{H}}=3.865 \mathrm{ppm}$, indicating this peak is assigned to a $\mathrm{H}(4)$ peak. The peaks at $\delta_{\mathrm{H}}=3.916$ and $3.943 \mathrm{ppm}$ closely correlate with the peaks at $\delta_{H}=$ 4.011 and $4.040 \mathrm{ppm}$ each other, strongly suggesting that these peaks split into quartet peaks assigned to non-equivalent two $\mathrm{H}(6)$ protons. A not-yet assigned $\mathrm{H}(5)$ peak may thus overlap with $\mathrm{H}(3)$ or $\mathrm{H}(4)$ peak, but the complex peak at $\delta_{\mathrm{H}}=3.7 \mathrm{ppm}$ is assigned to one of the $\mathrm{H}(5)$ sextet peaks correlated with $\mathrm{H}(6)$.

Figure 6 shows the ${ }^{13} \mathrm{C}-{ }^{1} \mathrm{H}$ COSY spectrum. Horizontal and longitudinal axes are ${ }^{13} \mathrm{C}$ and ${ }^{1} \mathrm{H}$ chemical shifts, respectively and projections on each axis are also shown. Peaks on 2D-spectrum clearly show C-H scalercoupling, indicating correlation between ${ }^{13} \mathrm{C}-{ }^{1} \mathrm{H}$ peaks. Based on the assignment on proton peaks, determined in Figures 4 and 5, two peaks at $\delta_{\mathrm{C}}=103.339$ and $74.347 \mathrm{ppm}$ in ${ }^{13} \mathrm{C}$ NMR spectrum are exactly assigned to the $C(1)$ and $C(2)$ carbon peaks. The carbon peak at $\delta_{\mathrm{C}}=79.584 \mathrm{ppm}$ shows cross correlation with the broad peak $\delta_{\mathrm{H}}=3.84 \mathrm{ppm}$, in which multiple peaks of $\mathrm{H}(4)$ proton are included. According to computer analysis on the chemical shifts in ${ }^{13} \mathrm{C}$ NMR spectrum using cellobiose as a model of cellulose, $\mathrm{C}(4)$ carbon chemical shift appears at the lowest magnetic field next to $\mathrm{C}(1)$ carbon, irrespective of the chain conformation of the cellobiose. ${ }^{20}$ From these facts, $\delta_{\mathrm{C}}=79.584 \mathrm{ppm}$ is

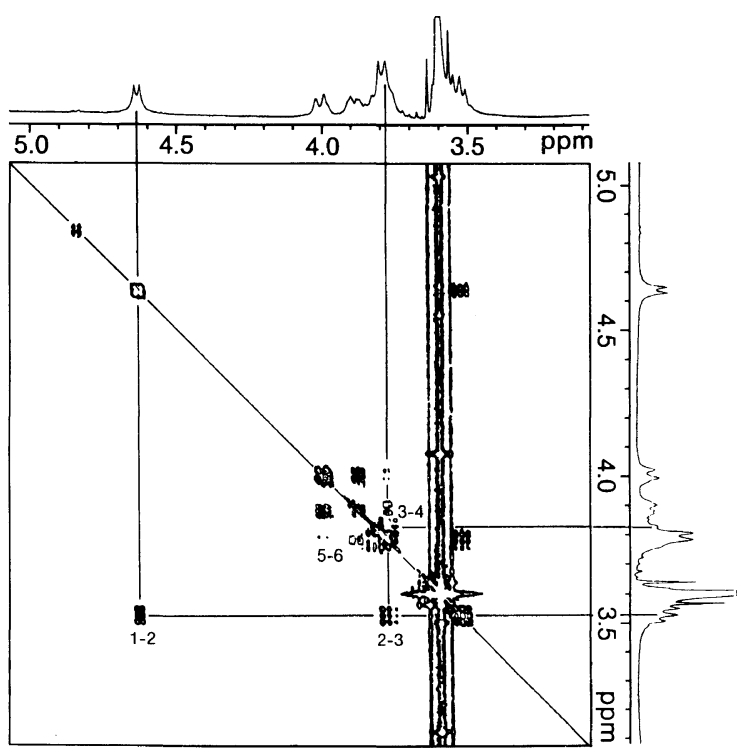

Figure 7. ${ }^{1} \mathrm{H}-{ }^{1} \mathrm{H}$ COSY spectrum of hydrolyzed regenerated cellulose with $D P_{\mathrm{v}}=30$ in $\mathrm{NaSCN}-\mathrm{D}_{2} \mathrm{O}$ system at $100^{\circ} \mathrm{C}$.

assigned to $\mathrm{C}(4)$ proton. The $\mathrm{C}(6)$ carbon peak is expected to be at highest magnetic field, because $\mathrm{C}(6)$ carbon is only one methylene carbon in the glucopyranose ring. All peaks except for that at $\delta_{\mathrm{C}}=62.234 \mathrm{ppm}$ closely correlate with proton peaks other than the $\mathrm{H}(6)$ proton peak. The peak at $\delta_{\mathrm{C}}=62.234 \mathrm{ppm}$ was thus assigned to $\mathrm{C}(6)$ carbon, while the correlation between the peak at $\delta_{\mathrm{C}}=62.234 \mathrm{ppm}$ and the $\mathrm{H}(6)$ peak was not observed. The reason is not clear and probably due to the measuring conditions although the same measuring conditions give a clear correlation of cellulose/aq NaSCN. The peak at $\delta_{\mathrm{C}}=75.334$ reveals coupling with triplet peaks at $\delta_{\mathrm{H}}=3.805,3.825$, and $3.845 \mathrm{ppm}$, leading to the conclusion that the peak at $\delta_{\mathrm{C}}=75.334 \mathrm{ppm}$ arises from $\mathrm{C}(3)$ carbon. Finally, the remaining unassigned carbon peaks at $\delta_{\mathrm{C}}=76.305 \mathrm{ppm}$, coupled with quartet proton peaks near $\delta_{\mathrm{H}}=3.84 \mathrm{ppm}$, might be attributed to $\mathrm{C}(5)$ peaks.

NMR Spectra of Cellulose/aq NaSCN Solution System

2D ${ }^{1} \mathrm{H}-{ }^{1} \mathrm{H}$ COSY spectra of cellulose with $D P_{\mathrm{v}}=30$ in $60 \mathrm{wt} \% \mathrm{NaSCN} / \mathrm{D}_{2} \mathrm{O}$ soln. is shown in Figure 7. According to analysis of the $1 \mathrm{D}{ }^{1} \mathrm{H}$ NMR spectrum of cellulose in aq $\mathrm{Ca}(\mathrm{SCN})_{2}-\mathrm{D}_{2} \mathrm{O}$ soln., the doublet peak near $\delta_{\mathrm{H}}=4.6 \mathrm{ppm}\left(\delta_{\mathrm{H}}=4.626\right.$ and $\left.4.646 \mathrm{ppm}\right)$, which appears at the lowest magnetic field, is assigned to anomeric proton at $\mathrm{C}(1)$ carbon position $(\mathrm{H}(1))$. The triplet proton peak in the range of $\delta_{\mathrm{H}}=3.55-3.50 \mathrm{ppm}$ in $1 \mathrm{D}$ spectrum, which reveals vicinal coupling with the $\mathrm{H}(1)$ peak, is attributed to $\mathrm{H}(2)$. The vicinal coupling triplet peak $\left(\delta_{\mathrm{H}}=3.803,3.781,3.756 \mathrm{ppm}\right)$ with $\mathrm{H}(2)$ proton peak is judged to arise from $\mathrm{H}(3)$ proton. Similarly, another triplet peak at $\delta_{\mathrm{H}}=3.849,3.829$, and $3.803 \mathrm{ppm}$ is assigned to $\mathrm{H}(4)$ proton. Here, the peaks at $\delta_{\mathrm{H}}=3.803 \mathrm{ppm}$ of $\mathrm{H}(3)$ and $\mathrm{H}(4)$ proton overlap each other. The doublet peak at $\delta_{\mathrm{H}}=4.108$ and $3.991 \mathrm{ppm}$ closely correlates with the other doublet peak at $\delta_{\mathrm{H}}=$ 3.898 and $3.879 \mathrm{ppm}$, strongly suggesting that these peaks split into quartet peaks assigned to non-equivalent two $\mathrm{H}(6)$ protons. The peak near $\delta_{\mathrm{H}}=3.8 \mathrm{ppm}$ which shows vicinal coupling with quartet peaks of $\mathrm{H}(6)$ protons 


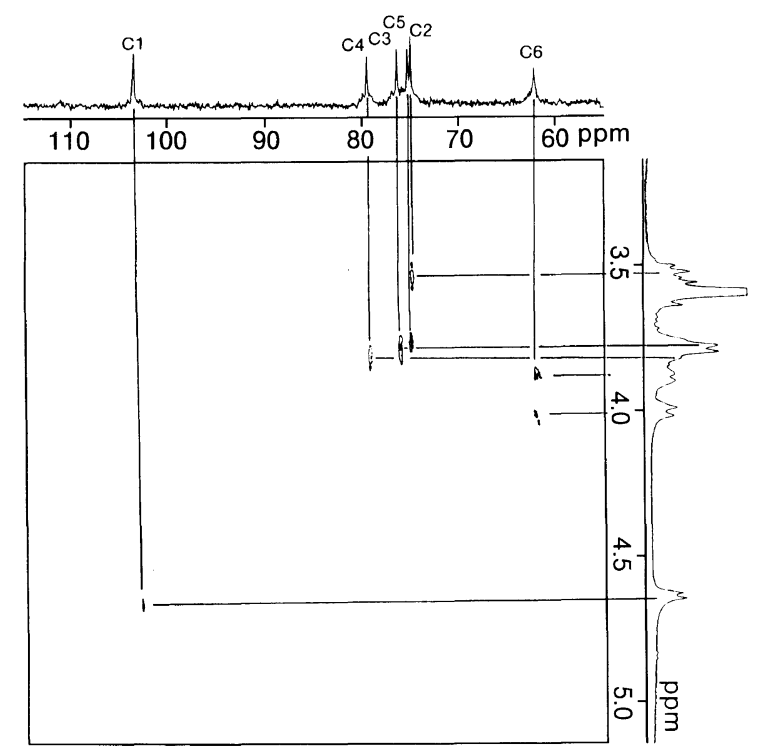

Figure 8. ${ }^{13} \mathrm{C}-{ }^{1} \mathrm{H} \quad \mathrm{COSY}$ spectrum of hydrolyzed regenerated cellulose with $D P_{v}=30$ in $\mathrm{NaSCN}-\mathrm{D}_{2} \mathrm{O}$ at $100^{\circ} \mathrm{C}$. Horizontal and longitudinal axes are ${ }^{13} \mathrm{C}$ and ${ }^{1} \mathrm{H}$ chemical shifts and projections on the axes are ${ }^{13} \mathrm{C}$ and ${ }^{1} \mathrm{H}$ NMR spectra, respectively.

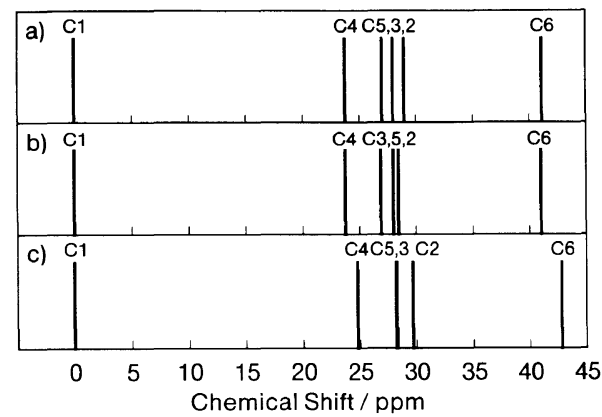

Figure 9. The chemical shifts of carbon peaks of cellulose from $\mathrm{C}(1)$ carbon position in $55 \mathrm{wt} \% \mathrm{Ca}(\mathrm{SCN})_{2}-\mathrm{D}_{2} \mathrm{O}$ (a), $60 \mathrm{wt} \% \mathrm{NaSCN}-\mathrm{D}_{2} \mathrm{O}$ (b), and $10 \mathrm{wt} \% \mathrm{NaOH}-\mathrm{D}_{2} \mathrm{O}$ (c).

is considered to be related to a part of $\mathrm{H}(5)$. Considering the peaks of $\mathrm{H}(5)$ is expected to be sextet peak from cellulose chemical sturucture, the peaks which appear at $\delta_{\mathrm{H}}=3.720,3.698,3.686 \mathrm{ppm}$ and shoulder of $\delta_{\mathrm{H}}=3.876$ ppm seem to be assigned $\mathrm{H}(5)$ proton.

In Figure 8, a stacked plot of the ${ }^{13} \mathrm{C}-{ }^{1} \mathrm{H}$ COSY spectrum is shown. On the basis of the assignment on proton peaks, determined in Figure 7 , three peaks at $\delta_{\mathrm{C}}=103.354,74.878$, and $62.340 \mathrm{ppm}$ in ${ }^{13} \mathrm{C} \mathrm{NMR}$ spectrum are exactly assigned to the $\mathrm{C}(1), \mathrm{C}(2)$, and $\mathrm{C}(6)$ carbon peaks. The peak at $\delta_{\mathrm{C}}=79.584 \mathrm{ppm}$ strongly correlates to the peak at $\delta_{\mathrm{H}}=3.829 \mathrm{ppm}$ and slightly to that at $\delta_{\mathrm{H}}=3.849$ and $3.803 \mathrm{ppm}$ of $\mathrm{H}(4)$ proton, showing that the peak at $\delta_{\mathrm{C}}=79.584 \mathrm{ppm}$ is attributed to $\mathrm{C}(4)$ carbon. Similarly, $\delta_{\mathrm{C}}=76.457 \mathrm{ppm}$ corresponds to the triplet peak at $\delta_{\mathbf{H}}=3.803,3.781$, and $3.756 \mathrm{ppm}$ of $\mathrm{H}(3)$ proton, suggesting that the carbon peak is $\mathrm{C}(3)$. Finally, unassigned peak at $\delta_{\mathrm{C}}=75.349 \mathrm{ppm}$ is concluded to be $\mathrm{C}(5)$ carbon.

\section{Dissolved Cellulose in aq Thiocyanate Solution}

In Figure 9, the chemical shifts of carbon peaks of cellulose in $55 \mathrm{wt} \% \mathrm{Ca}(\mathrm{SCN})_{2}-\mathrm{D}_{2} \mathrm{O}$ solution (a), $60 \mathrm{wt} \%$ $\mathrm{NaSCN}-\mathrm{D}_{2} \mathrm{O}$ solution (b), and $10 \mathrm{wt} \% \mathrm{NaOH}-\mathrm{D}_{2} \mathrm{O}$ solution $^{8}$ (c) are represented. In the figure, the position

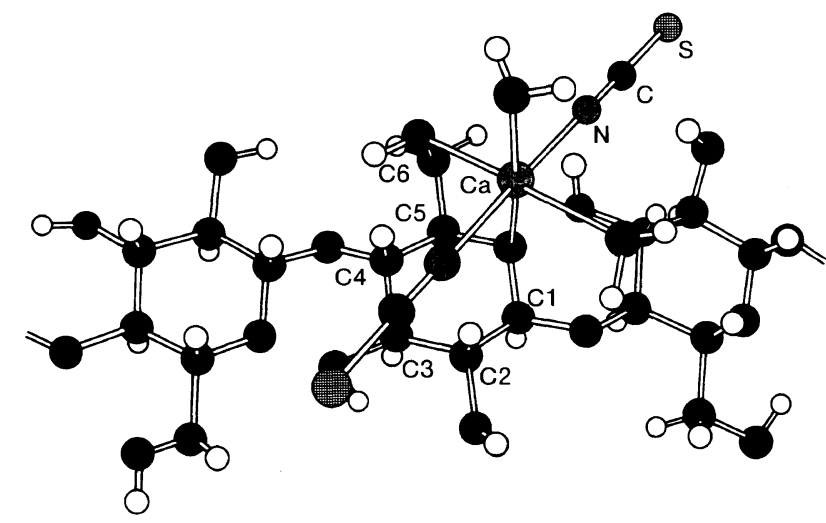

Figure 10. Interactions between cellulose and the calcium thiocyanate-water complex.

of chemical shift for $C(1)$ carbon in every spectrum is chosen as the standard, because $\mathrm{C}(1)$ carbon is considered not interact directly with solvent molecules as is the case of other solvent systems. ${ }^{3,21-26}$ In ${ }^{13} \mathrm{C}$ NMR spectra of cellulose in both thiocyanate solutions, the six carbon peaks corresponding to the carbons constituting a glucopyranose ring appear in similar manner as the NMR spectra of cellulose in cadoxen, ${ }^{22} 10 \% \mathrm{NaOH},{ }^{8}$ $\mathrm{N}$-methyl morpholine $\mathrm{N}$ oxide including water ${ }^{27}$ and DMAc- $\mathrm{LiCl}^{23}$ In these solvents, the cellulose is dissolved without forming any cellulose derivatives. Therefore, both thiocyanate solutions seem not to derivatize the cellulose. The characteristic feature of $\mathrm{Ca}(\mathrm{SCN})_{2}$ and $\mathrm{NaSCN}$ is that all carbon peaks, except for $\mathrm{C}(3)$ carbon peak of cellulose in $\mathrm{Ca}(\mathrm{SCN})_{2}$ and $\mathrm{C}(5)$ peak in $\mathrm{NaSCN}$, shift to lower magnetic fields, compared to the $10 \%$ aq $\mathrm{NaOH}$ soln. The relative position of $\mathrm{C}(3)$ and $\mathrm{C}(5)$ peaks in $\mathrm{Ca}(\mathrm{SCN})_{2}$ is different from that in $\mathrm{NaSCN}$. Kamide $e t$ al. ${ }^{25}$ proposed model on the dissolved state of cellulose in $8-10 \mathrm{wt} \%$ aq $\mathrm{NaOH}$ soln. That is, in the solvent system, one mole of dissociated sodium or hydroxyl ions is solvated with about four moles of water molecules and has loosely bonded water layer (2nd solvation area), but these $\mathrm{Na}$ and $\mathrm{OH}$ ions do not closely interact with specific position of cellulose molecule. Note that the prerequisite is that in this state $\mathrm{C}(3)-\mathrm{OH} \cdots \mathrm{O}\left(5^{\prime}\right)$ intramolecular hydrogen bonds are broken. As described before, in the aq $\mathrm{Ca}(\mathrm{SCN})_{2}$ soln., undissociated $\mathrm{Ca}(\mathrm{SCN})_{2}$ molecules form complexes with water molecules and in the mixture of cellulose-aq $\mathrm{Ca}(\mathrm{SCN})_{2}$ soln., calcium atoms of the complex coordinate with ring oxygen $(\mathrm{O}(5))$ and hydroxyl oxygen at $\mathrm{C}(6)$ position $(\mathrm{O}(6))$, as shown in Figure 10. It is plausible to consider that $\mathrm{C}(5)$ and $\mathrm{C}(6)$ carbon peak of cellulose in aq $\mathrm{Ca}(\mathrm{SCN})_{2}$ soln. might shift to lower magnetic fields, compared with cellulose in aq $\mathrm{NaOH}$ soln., C(3) carbon should be in non-intramolecular hydrogen bonded state as is the case of cellulose/aq $\mathrm{NaOH}$ system, suggesting the chemical shifts of $\mathrm{C}(3)$ in aq $\mathrm{NaOH}$ and aq $\mathrm{Ca}(\mathrm{NCS})_{2}$ are in a similar region, as proved in Figure 9. A possible interaction model between calcium thiocyanate hydrate and cellulose is shown in Figure 10, suggesting that $\mathrm{C}(2)$ carbon is located in the deshielding area from $-\mathrm{N}=\mathrm{C}=\mathrm{S}$ parts of $\mathrm{Ca}(\mathrm{NCS})_{2}$. $2 \mathrm{H}_{2} \mathrm{O}$, as cellulose solvents or $\pi$ electron surrounding $-\mathrm{N}=\mathrm{C}=\mathrm{S}$ might interact with hydroxyl proton on $\mathrm{C}(2)$ carbon, leading to lower magnetic field shifts of $\mathrm{C}(2)$ carbon, compared with that in aq $\mathrm{NaOH}$. 
In the spectrum of cellulose $60 \mathrm{wt} \% \mathrm{NaSCN} / \mathrm{D}_{2} \mathrm{O}$, $\mathrm{C}(2), \mathrm{C}(3)$, and $\mathrm{C}(6)$ peaks shift to far lower magnetic field than that of $10 \% \mathrm{NaOH}$, respectively, while only the $\mathrm{C}(5)$ peak remains unmoved. This strongly suggests that $\mathrm{Na}$ atoms interact with three hydroxyl groups in the glucopyranose ring of the cellulose and do not coordinate with $\mathrm{O}(5)$ in the glucopyranose. This seems the reason why the concentrated aq NaSCN soln. is able only to dissolve cellulose solid in which at least half the intra- and intermolecular hydrogen bonds are perfectly broken.

The chemical shifts of $\mathrm{C}(4)$ carbon estimated by computer analysis on the cellobiose as a model of cellulose appear between $C(1)$ and $C(3)$ carbon chemical shifts due to chain conformation represented by torsional angle around the bridge oxygen. ${ }^{20}$ From these results, cellulose molecules in the two thiocyanate solvents are considered to take quite different conformation from in the $10 \% \mathrm{NaOH}$ system.

\section{CONCLUSION}

Almost all celluloses are soluble in $55 \mathrm{wt} \%$ aq $\mathrm{Ca}(\mathrm{SCN})_{2}$ soln. above $c a \cdot 100^{\circ} \mathrm{C}$, while $60 \mathrm{wt} \%$ aq NaSCN soln. dissolves very limited cellulose mainly regenerated from cellulose solution. The solubility of the cellulose in aq $\mathrm{NaSCN}$ soln. is independent of crystal form, crystallinity, and degree of polymerization of the cellulose samples and determined by the degree of breakdown of intramolecular hydrogen bond as is the case of $9 \%$ aq $\mathrm{NaOH}$ soln. at $4^{\circ} \mathrm{C}$. Comparison of carbon chemical shifts of cellulose in aq calcium thiocyanate soln. with $10 \%$ aq $\mathrm{NaOH}$ soln. implies that calcium atoms coordinate with oxygen atoms in skeletal glucose ring and in primary alcohol at $\mathrm{C}(6)$ position, as has been pointed out by the authors. ${ }^{13}$ From the carbon chemical shifts of $\mathrm{C}(3), \mathrm{C}(2)$, and $\mathrm{C}(6)$ carbons of cellulose in aq $\mathrm{NaSCN}-\mathrm{D}_{2} \mathrm{O}$ soln., sodium atom was considered to closely interact with all hydroxyl oxygen atoms of the glucopyranose ring of cellulose molecules in solution.

Acknowledgment. The authors would express thanks to Dr. K. Okajima, Director of our company, for valuable discussion.

\section{REFERENCES}

1. S. M. Hudson and J. A. Cuculo, J. Macromol. Sci., Rev. Macromol. Chem., C18, 1(1980).

2. C. L. McCormick and D. K. Lichatowich, J. Polym. Sci., Polym. Lett. Ed., 17, 479 (1979).

3. C. L. McCormick, P. A. Callais, and B. H. Hutchinson, Jr., Macromolecules, 18, 2394 (1985).

4. H. Chanzy and A. Peguy, J. Polym. Sci., Polym. Phys. Ed., 18, 1137 (1980).

5. J. A. Cuculo, C. B. Smith, U. Sangwatanaroj, E. O. Stejskal, and S. S. Sankar, J. Polym. Sci., Polym. Chem., 32, 229 (1994).

6. J. A. Cuculo, C. B. Smith, U. Sangwatanaroj, E. O. Stejskal, and S. S. Sankar, J. Polym. Sci., Part A, Polym. Chem., 32, 241 (1994).

7. K. Kamide and K. Okajima, US Patent 4,634,470 (1987).

8. K. Kamide, K. Okajima, T. Matsui, and K. Kowsaka, Polym. J., 16, 857 (1984).

9. K. Kamide, K. Okajima, and K. Kowsaka, Polym. J., 24, 71 (1992).

10. M. Saito and Y. Shimaya, Japanese Applied Patent, P06-291125 (1994).

11. Y. Shimaya and M. Saito, Japanese Applied Patent P06-291124 (1994).

12. M. Hattori, Y. Shimaya, and M. Saito, Polym. J., 30, 37 (1998).

13. M. Hattori, T. Koga, Y. Shimaya, and M. Saito, Polym. J., 30, 43 (1998).

14. K. Okajima, Y. Matsuda, and K. Kamide, Polym. International, 25, 145 (1991).

15. K. Nakama, M. Wada, T. Okano, and J. Sugiyama, Preprints of '95 Cellulose R\&D, 2nd Annual Meeting of the Cellulose Society of Japan, 1995, p 83.

16. P. Scherrer, Gottinger Nachr., 98 (1918).

17. W. Brown and R. Wikström, Eur. Polym. J., 1, 1 (1966).

18. See for example, J. Sugiyama, Cell. Commun., 1, 6 (1994).

19. A. E. Derome, "Modern NMR Techniques for Chemistry Research," Pargamon Books Ltd., Oxford, Japanese translation right arranged with Pargamon Books Ltd. through Japan UNI Agency, Inc., Tokyo, 1991, Chapter 8, p 213.

20. I. Miyamoto, M. Saito, and K. Okajima, Preprints of ' 95 Cellulose R\&D, 2nd Annual Meeting of Cellulose Society of Japan, 1995, p 19. The paper is accepted to Sen'i Kikai Gakkai Shi.

21. B. Lindberg and B. Swan, Acta Chem. Scand., 17, 913 (1963)

22. A. D. Bain, D. R. Eaton, R. A. Hux, and J. P. K. Tong, Carbohydrate Res., 84, 1 (1980).

23. A. El-Kafrawy, J. Appl. Polym. Sci., 27, 2435 (1982)

24. J. S. Germain and M. Vincendon, Organic Magnetic Resonance, 21, 371 (1983).

25. E. R. Maia and S. Perez, Nouveau J. Chimie, 7, 89 (1983).

26. K. Kamide, K. Yasuda, T. Matsui, K. Okajima, and T. Yamashiki, Cellulose Chemistry and Technology, 24, 23 (1990).

27. I. Nehls, B. Lukanoff, B. Philipp, and A. Zschunke, Acta Polymerica, 34, 105 (1983). 